\title{
Editorial
}

\section{Mineralogy and petrology of alkaline rocks and carbonatites: Celebrating the life and work of Gregory Yu. Ivanyuk (1966-2019)}

\author{
Anatoly N. Zaitsev ${ }^{1,2 *}$, Anton R. Chakhmouradian ${ }^{3}$, Sergey V. Krivovichev ${ }^{4,5}$ and Victor N. Yakovenchuk ${ }^{4}$ \\ ${ }^{1}$ Department of Mineralogy, St. Petersburg State University, $7 / 9$ University Emb, St. Petersburg 199034, Russia; ${ }^{2}$ Imaging and Analysis Centre, Department of Earth \\ Sciences, The Natural History Museum, Cromwell Road, SW7 5BD, UK; ${ }^{3}$ Department of Geological Sciences, University of Manitoba, 125 Dysart Road, Winnipeg, \\ Manitoba, R3T 2N2, Canada; ${ }^{4}$ Kola Science Centre, Russian Academy of Sciences, 14 Fersman Street, Apatity 184200, Russia; and ${ }^{5}$ Department of Crystallography, \\ St. Petersburg State University, 7/9 University Emb., St. Petersburg 199034, Russia
}

This issue of Mineralogical Magazine is dedicated to the memory of Gregory (Grisha) Yu. Ivanyuk (1966-2019), an internationally acclaimed mineralogist, an accomplished artist and photographer, and a tireless explorer of the Kola wilderness (Fig. 1). Grisha passed away suddenly on July 7, 2019, during a field excursion to Mt. Eveslogchorr in the Khibiny (also known as Khibina) alkaline complex, Kola Peninsula, Russia. This was the very place where he started his mineralogical studies of the region back in 1988. At the time of his untimely death, he was bursting with energy, plans and ideas. None of us who knew him could expect such a sudden and unjust disruption of this singularly dynamic life and research career.

Gregory was born on February 23, 1966, in Perm, a city with a 300 -year history of mineral exploration which is also the namesake of the Permian Period and stratigraphic system. In 1983, he enrolled at the Faculty of Geology in Leningrad State University (LGU, now St. Petersburg State University), where he majored in Mineralogy. During these formative years, Gregory became first exposed to, and fell in love with, alkaline rocks and carbonatites, particularly after his trip to the Murun charoite deposit in Siberia. This interest was fermented by his research supervisors, Professor Andrei G. Bulakh (1933-2020) and Dr. Mikhail D. Evdokimov (1940-2011), whose scientific interests included the mineralogy and petrology of world-famous alkaline intrusions in the Kola Peninsula, northern Karelia and East Siberia. Not surprisingly, Gregory's first peer-reviewed publication was a study of Murun pyroxenes, beautifully illustrated with his own hand drawings (Ivanyuk and Evdokimov, 1991).

Gregory graduated in 1988, back in the days when university graduates were expected to 'work off their free education for three years at an assigned place of employment, sometimes quite remote from one's home or Alma Mater. Gregory was fortunate enough to land a job at the Geological Institute of the Kola Branch of the USSR Academy of Sciences in Apatity, a mediumsized town of scientists and miners in the foothills of the worldfamous Khibiny mountains. Located in the heart of the Kola

\footnotetext{
*Author for correspondence: Anatoly N. Zaitsev, Email: a.zaitsev@spbu.ru This paper is part of a thematic set 'Alkaline Rocks' in memory of Dr Gregory Yu. Ivanyuk

Cite this article: Zaitsev A.N., Chakhmouradian A.R., Krivovichev S.V. and Yakovenchuk V.N. (2021) Mineralogy and petrology of alkaline rocks and carbonatites: Celebrating the life and work of Gregory Yu. Ivanyuk (1966-2019). Mineralogical Magazine 85, 465-468 https://doi.org/10.1180/mgm.2021.52
}

Peninsula in the western part of the Russian Arctic, the Khibiny and nearby Lovozero tundras are probably the oldest known and best-studied alkaline intrusions in the world. At the institute, Gregory's PhD work was supervised by Professor Pavel M. Goryainov (1937-2019), who immediately recognised the exceptional talent and dynamic personality of his new student. Their productive research collaboration grew into a long-time friendship, which ended only with Goryainov's demise on February 23 of 2019, on Gregory's birthday and just a few months before his own passing. In 1992, Gregory defended his PhD dissertation, on 'Magnetite of Banded Iron Formations of the Kola Peninsula'.

Just one year after his move to Apatity, Gregory married a fellow LGU graduate and mineralogist, Ayya Bazai. Over 30-plus years of their happy marriage (and scientific collaboration!), they have had welcomed into this world daughters Viya and Polina, son Mikhail and three grandchildren: Aglaya, Lizaveta and Ostap (Fig. 2). Gregory's son-in-law, Dr Taras Panikorovskii is one of the contributing authors in the present issue.

Gregory's scientific career progressed rapidly, fuelled by his determination, vitality and inquisitive mind. Beyond traditional mineralogy, his research interests expanded into the field of selforganising mineral systems, a topic he would come to explore in great depth together with his former $\mathrm{PhD}$ supervisor Pavel Goryainov. Gregory quickly rose through the academic ranks to become first Head of the Laboratory of Self-Organisation in Mineral Systems (2003) and then Vice-President of the entire Kola Science Centre (2017) of the Russian Academy of Sciences (KSC RAS). In 2004, Gregory defended his DSc dissertation (equivalent to Habilitation) focused on the 'Mineralogy and Petrology of Banded Iron Formation Deposits in the Kola Peninsula'. Ivanyuk and Goryainov's 'self-organisation' team published two books on this expansive subject (Goryainov and Ivanyuk, 2001; Bazai et al., 2009), which were highly appraised by the Nobel laureate and one of the fathers of non-equilibrium thermodynamics Ilya Prigogine, who even wrote a letter to the Russian Foundation for Fundamental Research, urging them to provide additional financial support to Ivanyuk and Goryainov's efforts. It is noteworthy here that Gregory's interests in Kola rocks were not purely theoretical and he made a lasting contribution to our understanding of mineral deposits as diverse as iron formations, phoscorites and apatite ores, particularly in his latter years and in collaboration with his younger colleagues (Ivanyuk 


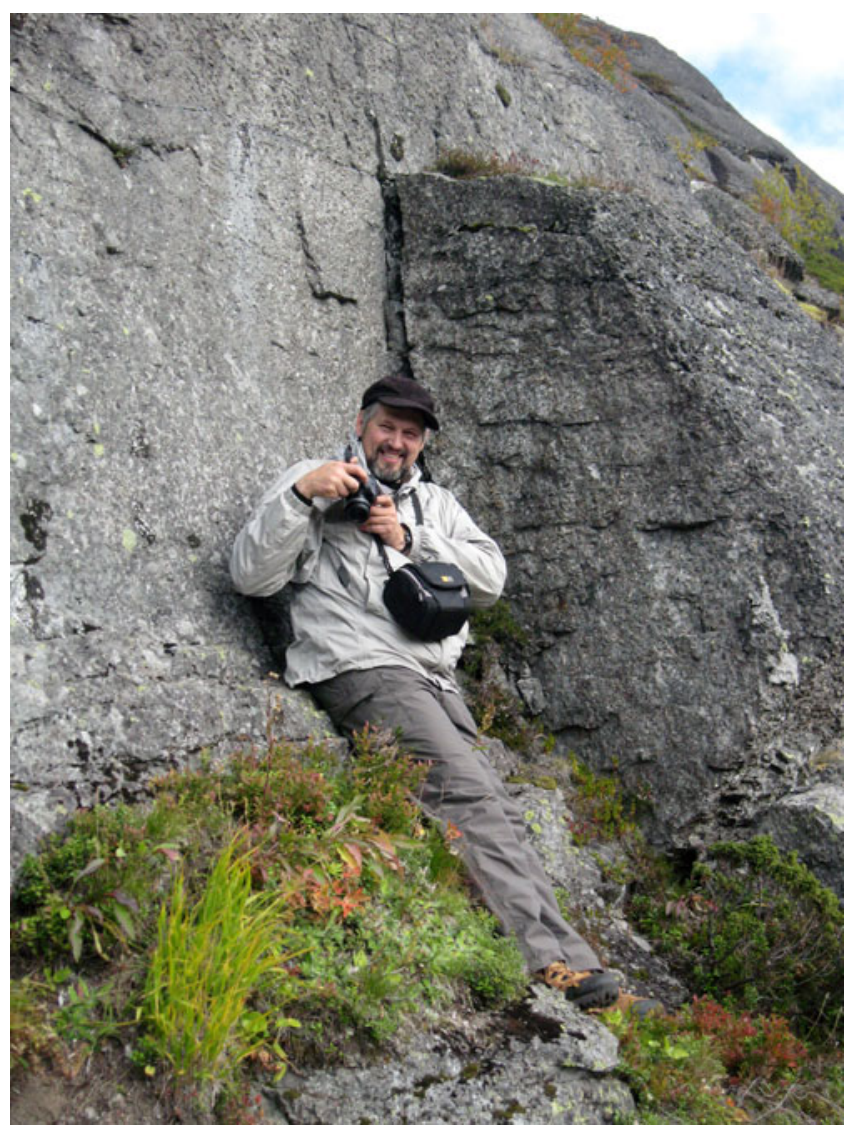

Fig. 1. Gregory enjoying a sunny day of fieldwork on the slope of Mt. Ninchurt, Lovozero Mts. (2018).

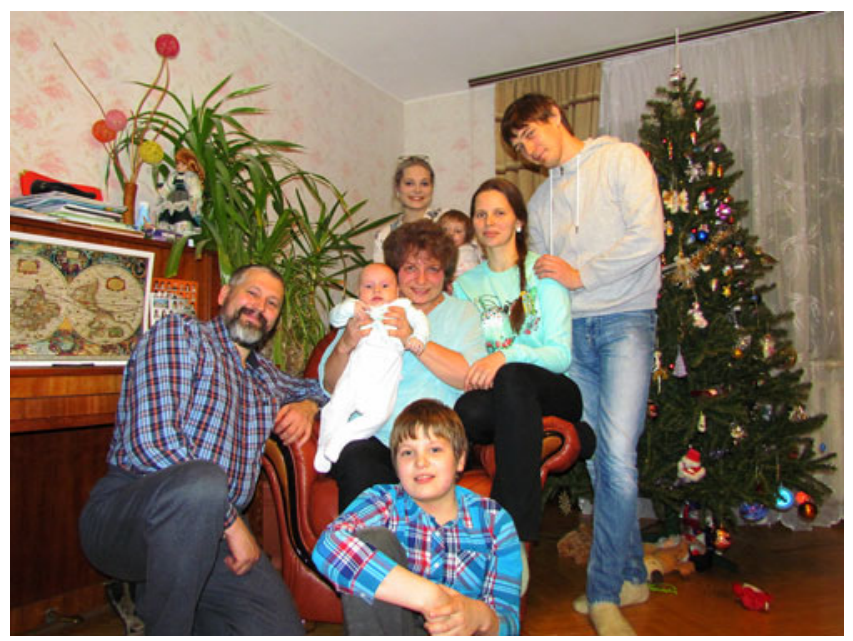

Fig. 2. Ivanyuk family gathering on 2016 New Year's Eve: Mikhail (front centre), Gregory, Ayya with grandson Ostap, Viya and Taras (from left to right), Polina with Aglaya (back).

et al., 2016, 2018a, b; Kalashnikov et al., 2016, 2017; Mikhailova et al., 2016, 2017, 2018).

At the KSC RAS, Gregory was also a key member of a dynamic research team whose primary focus was the detailed characterisation of new and poorly understood mineral species, most of which were collected on the snow-patched slopes of Khibiny, on the

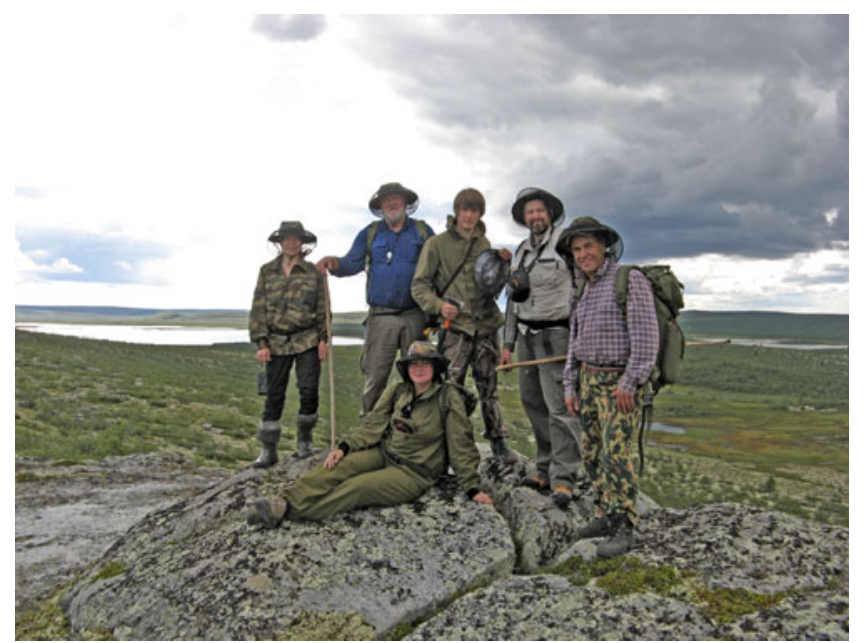

Fig. 3. Fieldtrip to granites and pegmatites in Western Keivy, Kola (2012): Yuliya Mikhailova (front center), Ekaterina Fomina, Viktor Yakovenchuk, Taras Panikorovskii, Gregory Ivanyuk and Yakov Pakhomovsky (from left to right).

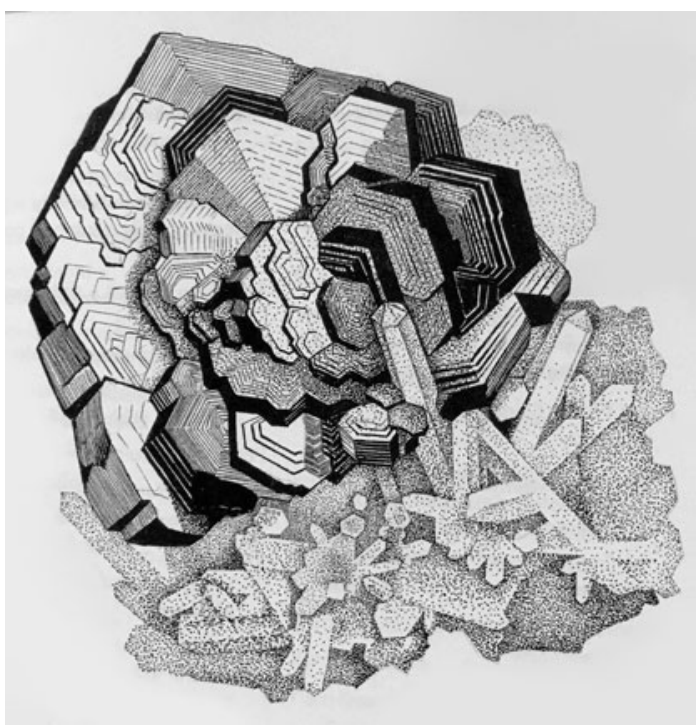

Fig. 4. Ink drawing of pyrrhotite and quartz crystal druse from the Dal'negorsk deposit, Far East.

rocky Lovozero plateau, or elsewhere in Kola by themselves using old maps and field records, or oftentimes just 'going by the hunch' (Fig. 3). All members of their team, including Yuriy P. Men'shikov (1934-2013), Viktor N. Yakovenchuk, Sergey N. Britvin (presently at St. Petersburg State University) and Yakov A. Pakhomovsky, are remarkable rockhounds and outdoor enthusiasts who reinvestigated numerous 'lost' mineral localities and put a great many new ones on the Kola map. As was always the case with Gregory, their long collaboration was extremely productive, leading to the discovery of 22 new minerals and the publication of splendidly illustrated and meticulously detailed volumes on the mineralogy of the Khibiny and Kovdor alkaline complexes (Yakovenchuk et al., 1999, 2005; Ivanyuk et al., 2002). Gregory was also an outstanding photographer and sketch artist (Fig. 4); his unique vision of light and form is amply showcased in the above monographs, in a poetic pictorial on Khibiny 


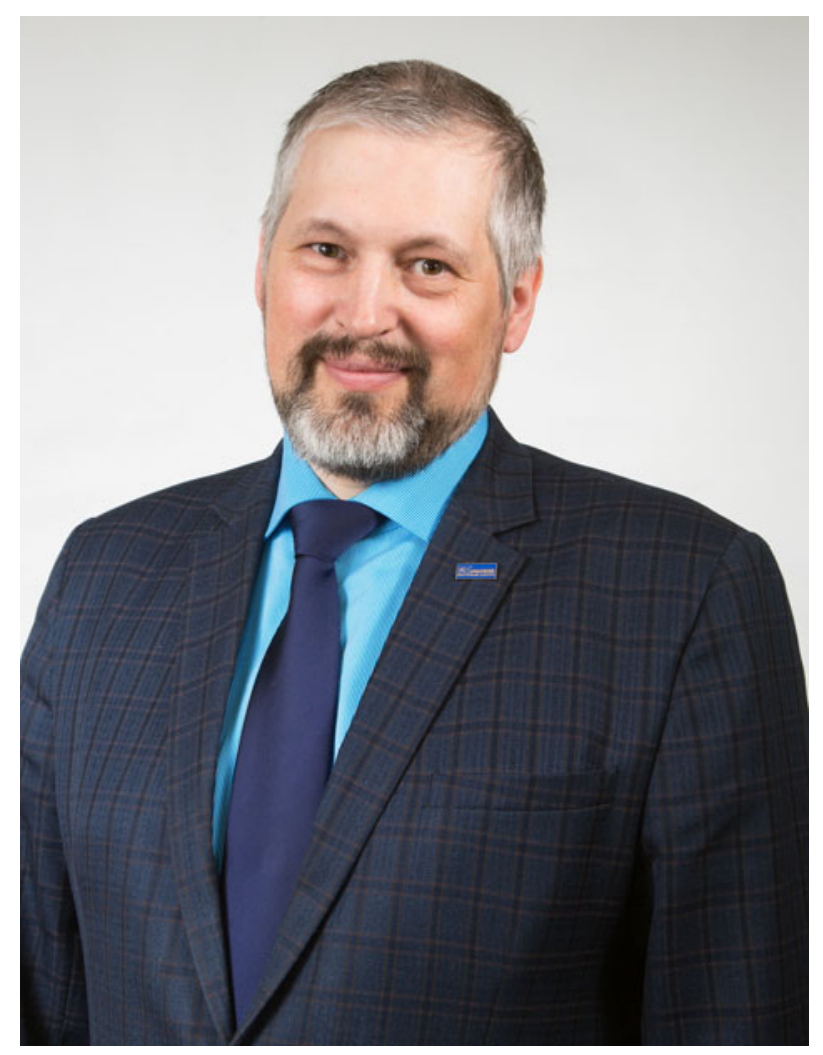

Fig. 5. Gregory Ivanyuk as newly elected Vice-President of the Kola Science Centre of the Russian Academy of Sciences (2018).

(Ryabkov et al., 1998), as well as in Robinson's profile article in Rocks and Minerals (2010).

In 2017, Gregory was appointed Vice-President of the KSC RAS (Fig. 5), a unique structure that encompasses ten institutes covering the complete range of polar research, from geology, mining and metallurgy to the history of the Barents Sea region, environmental stewardship and the well-being of indigenous peoples in the Arctic. Gregory's organisational skills, scientific reputation and benevolence made him a highly respected administrator by all KSC RAS staff. There were no signs of trouble that led to Grisha's unexpected demise on the sunny and windy day of July 7, 2019. However, his name lives on in not just one, but a whole family of titanosilicate minerals (Yakovenchuk et al., 2009), and his torch has been picked up by Gregory's students and younger colleagues.

The current issue is a collection of articles that reflect on Gregory's scientific interests and, in some cases, build on his contributions to what we know about alkaline rocks and their spectacular minerals.

The issue opens with a geochronological study of carbonatites and jacupirangite from the Guli complex in Polar Siberia, where Reguir et al. (2021) provide new U-Pb constraints for temporal relations between alkaline-carbonatitic magmatism and flood basalts. They present an improved methodology for the radiometric age determination of perovskite using a non-matrix-matched standard and reach an intriguing conclusion that the Guli complex may have taken longer to form than previously recognised. The paper by Mitchell and Dawson (2021) discusses the applicability of the alteration model, originally proposed for gregoriteand nyerereite-bearing natrocarbonatites from the active Oldoinyo Lengai volcano, to carbonatites at the extinct Kerimasi and Tinderet volcanoes in East Africa. These authors suggest that calcite phenocrysts in these lavas cannot be pseudomorphs after nyereryite or gregoryite.

Six papers in this issue are focused on petrologically and economically important minerals in carbonatites and alkaline rocks. The contribution by Sitnikova et al. (2021) describes the occurrence of burbankite and other rare earth element (REE) phases in carbonatites at Lofdal, Namibia. This locality is known as a potential source of $\mathrm{Y}$ and heavy rare earths; however Sitnikova et al. emphasise the importance of light-REE mineralisation. Burbankite is considered a primary magmatic constituent of calcite carbonatites, which was replaced at late hydrothermal stages by a complex assemblage of Ba-Sr-REE minerals. Le Bras et al. (2021) applied micro-focus X-ray computed tomography to investigate sulfide-rich phoscorites and carbonatites from the Phalaborwa complex, South Africa. Their data show that threedimensional textural analysis is effective for the characterisation of magma flow and understanding of the processes that control sulfide mineralisation (bornite, chalcopyrite, cubanite and valleriite) in phoscorites and carbonatites.

Pyrochlore-group minerals are the focus of the following four papers. Zaitsev et al. (2021) describe the internal zoning, composition and crystal structure of pyrochlore from the Kerimasi carbonatites. The mineral is characterised by exceptionally well-preserved oscillatory- and sector-type zoning, contains elevated levels of $\mathrm{U}$ and $\mathrm{Zr}$ and all minerals, including the $\mathrm{U}$-rich types, are crystalline. This locality is a rare example of carbonatites where pyrochlore lacks low-temperature alteration and metamictisation. The paper by Viladkar and Sorokhtina (2021) describes pyrochlore from the Amba Dongar carbonatites in India. The authors discuss compositional evolution from primary magmatic to diverse late-stage hydrothermal minerals and compare new data with published data for pyrochlore from other Indian carbonatites. Two papers by Dey et al. (2021a, b) report the paragenesis and compositional variation of different pyrochlore populations in albitites, dolomite and silicate-rich carbonatites from the Sevattur carbonatite complex, India. These contributions record complex crystallisation histories of the Sevattur rocks under magmatic and hydrothermal conditions. All four papers also discuss the nomenclature of pyrochlore group and explore the strengths and weaknesses of the classification schemes proposed by Hogarth (1977) and Atencio et al. (2010).

The issue concludes with three mineralogical crystallography papers. Panikorovskii et al. (2021) report the results of a structural and compositional study of ivanyukite-group minerals. These minerals are based on a heteropolyhedral framework of pharmacosiderite topology and possess unique cation-exchange properties, which make them highly promising for applications in nuclear waste disposal. The paper by Krivovichev et al. (2021) presents a crystal-structure analysis and description of nikmelnikovite, the first trigonal member of the garnet supergroup discovered recently at Kovdor, one of Gregory's favourite places of work and contemplation. The authors compare the crystal structure of nikmelnikovite with the ideal cubic garnet structure to demonstrate their crystalchemical relations. Finally, Zubkova et al. (2021) provide interesting data on a previously unknown, hydrated variety of the microporous zirconosilicate elpidite from Khibiny. They demonstrate exceptional flexibility of the octahedral-tetrahedral framework of elpidite, which allows for different hydration states of its interstitial constituents.

We hope that the present collection of articles will serve as a worthy tribute to the outstanding scientist, luminous person and faithful friend Gregory Ivanyuk, and will move our younger readers to look to alkaline rocks for inspiration. 
Acknowledgements. This issue would not have been possible without the expert help of Principal Editors Roger H. Mitchell, Stuart Mills and Production Editor Helen Kerbey, nor without the many dedicated people who generously volunteered their time to review the manuscripts.

\section{References}

Atencio D., Andrade M.B., Christy A.G., Gieré R. and Kartashov P.M. (2010) The pyrochlore supergroup of minerals: nomenclature. The Canadian Mineralogist, 48, 673-698.

Bazai A.V., Goryainov P.M., Ivanyuk G.Yu., Kalashnikov A.O., Konopleva N.G., Pakhomovsky Ya.A. and Yakovenchuk V.N. (2009) Self-Organization of Ore Complexes. Synergetic Principles of Prognostication and Search for Mineral Deposits. Moscow, GEOCART-GEOS, 392 pp. [in Russian].

Dey M., Bhattacharjee S., Chakrabarty A., Mitchell R.H., Pal S., Pal S. and Sen A.K. (2021b) Compositional variation and genesis of pyrochlore, belkovite and baotite from the Sevattur carbonatite complex, India. Mineralogical Magazine, 85, https://doi.org/10.1180/mgm.2021.6.

Dey M., Mitchell R.H., Bhattacharjee S., Chakarabarty A., Pal S., Pal S. and Sen A.K. (2021) Composition and genesis of albitite-hosted antecrystic pyrochlore from the Sevattur carbonatite complex, India. Mineralogical Magazine, 85, https://doi.org/10.1180/mgm.2021.37

Goryainov P.M. and Ivanyuk G.Yu. (2001) Self-Organization of Mineral Systems. Synergetic Principles of Geological Studies. Moscow, GEOS, 312 pp. [in Russian].

Hogarth D.D. (1977) Classification and nomenclature of the pyrochlore group minerals. American Mineralogist, 62, 403-410.

Ivanyuk G.Yu. and Evdokimov M.D. (1991) Pyroxenes of the "Lilac Rock" charoite deposit and some characteristics of their genesis. Zapiski Vsesoyuznogo Mineralogicheskogo Obshchestva, 3, 62-74 [in Russian].

Ivanyuk G.Y., Yakovenchuk V.N. and Pakhomovsky Ya.A. (2002) Kovdor. Apatity, Laplandia minerals. $321 \mathrm{pp}$.

Ivanyuk G.Yu., Kalashnikov A.O., Pakhomovsky Ya.A., Mikhailova J.A., Yakovenchuk V.N., Konopleva N.G., Sokharev V.A., Bazai A.V. and Goryainov P.M. (2016) Economic minerals of the Kovdor baddeleyite-apatite-magnetite deposit, Russia: Mineralogy, spatial distribution and ore processing optimization. Ore Geology Reviews, 77, 279-311.

Ivanyuk G.Yu., Pakhomovsky Ya.A., Panikorovskii T.L., Mikhailova J.A., Kalashnikov A.O., Bazai A.V., Yakovenchuk V.N., Konopleva N.G. and Goryainov P.M. (2018a) 3-D mineralogical mapping of the Kovdor phoscorite-carbonatite complex, NW Russia: II. Sulfides. Minerals, 8, 292.

Ivanyuk G.Yu., Konopleva N.G., Yakovenchuk V.N., Pakhomovsky Ya.A., Panikorovskii T.L., Kalashnikov A.O., Bocharov V.N., Bazai A.A., Mikhailova J.A. and Goryainov P.M. (2018b) 3-D mineralogical mapping of the Kovdor phoscorite-carbonatite complex, NW Russia: III. Pyrochlore supergroup minerals. Minerals, 8, 277.

Kalashnikov A.O., Konopleva N.G., Pakhomovsky Ya.A. and Ivanyuk G.Yu. (2016) Rare earth deposits of the Murmansk Region, Russia - A review. Economic Geology, 111, 1529-1559.

Kalashnikov A.O., Ivanyuk G.Yu., Mikhailova J.A. and Sokharev V.A. (2017) Approach of automatic 3D geological mapping: The case of the Kovdor phoscorite-carbonatite complex, NW Russia. Scientific Reports, 7, 6893.

Krivovichev S.V., Panikorovskii T.L., Yakovenchuk V.N., Selivanova E.A. and Ivanyuk G.Yu. (2021) Trigonal variations in the garnet supergroup: the crystal structure of nikmelnikovite, $\mathrm{Ca}_{12} \mathrm{Fe}^{2+} \mathrm{Fe}_{3}^{3+} \mathrm{Al}_{3}\left(\mathrm{SiO}_{4}\right)_{6}(\mathrm{OH})_{20}$, from Kovdor massif, Kola peninsula, Russia. Mineralogical Magazine, 85, https://doi.org/10.1180/mgm.2021.55.
Le Bras L.Y., Bolhar R., Bam K., Guy B.M., Bybee G.M. and Nex P.A.M. (2021) Three-dimensional textural investigation of sulfide mineralisation from the Loolekop carbonatite-phoscorite polyphase intrusion in the Phalaborwa Igneous Complex (South Africa), with implications for ore-forming processes. Mineralogical Magazine, 85, https://doi.org/10.1180/mgm.2021.32.

Mikhailova J.A., Kalashnikov A.O., Sokharev V.A., Pakhomovsky Ya.A., Konopleva N.G., Yakovenchuk V.N., Bazai A.V., Goryainov P.M. and Ivanyuk G. Yu. (2016) 3D mineralogical mapping of the Kovdor phoscorite-carbonatite complex (Russia). Mineralium Deposita, 51, 131-149.

Mikhailova J.A., Pakhomovsky Ya.A., Ivanyuk G.Yu., Bazai A.V., Yakovenchuk V.N., Elizarova I.R. and Kalashnikov A.O. (2017) REE mineralogy and geochemistry of the Western Keivy peralkaline granite massif, Kola Peninsula, Russia. Ore Geology Reviews, 82, 181-197.

Mikhailova J.A., Ivanyuk G.Yu., Kalashnikov A.O., Pakhomovsky Ya.A., Bazai A.V., Panikorovskii T.L., Yakovenchuk V.N., Konopleva N.G. and Goryainov P.M. (2018) 3-D mineralogical mapping of the Kovdor phoscorite-carbonatite complex, NW Russia: I. Forsterite. Minerals, 8, 260.

Mitchell R.H and Dawson J.B. (2021) Mineralogy of volcanic calciocarbonatites from the Trig Point Hill debris flow, Kerimasi volcano, Tanzania: implications for the altered natrocarbonatite hypothesis. Mineralogical Magazine, 85, https://doi.org/10.1180/mgm.2020.97.

Panikorovskii T.L., Yakovenchuk V.N., Yanicheva N.Yu., Pakhomovsky Ya.A., Shilovskikh V.V., Bocharov V.N. and Krivovichev, S.V. (2021) Crystal chemistry of ivanyukite group minerals, $A_{3-\mathrm{x}} \mathrm{H}_{1+\mathrm{x}}\left[\mathrm{Ti}_{4} \mathrm{O}_{4}\left(\mathrm{SiO}_{4}\right)_{3}\right]\left(\mathrm{H}_{2} \mathrm{O}\right)_{\mathrm{n}}$ $(A=\mathrm{Na}, \mathrm{K}, \mathrm{Cu}),(n=6-9, x=0-2)$ : crystal structures, ion-exchange, chemical evolution. Mineralogical Magazine, 85, https://doi.org/10.1180/ mgm.2021.51.

Reguir E.P., Salnikova E.B., Yang P., Chakhmouradian A.R., Stifeeva M.V., Rass I.T. and Kotov A.B. (2021) U-Pb geochronology of calcite carbonatites and jacupirangite from the Guli alkaline complex, Polar Siberia, Russia. Mineralogical Magazine, 85, https://doi.org/10.1180/mgm.2021.53.

Ryabkov I., Ivanyuk G., Yakovenchuk V. (1998) The Splendour of the Khibiny. Apatity, Kola Science Centre RAS, 125 p.

Sitnikova M.A., Do Cabo V., Wall F., Goldmann S. (2021) Burbankite and pseudomorphs from the Main Intrusion calcite carbonatite, Lofdal, Namibia: association, mineral chemistry, Raman spectroscopy. Mineralogical Magazine, 85, https://doi.org/10.1180/mgm.2021.56.

Viladkar S.G. and Sorokhtina N.V. (2021) Evolution of pyrochlore in carbonatites of the Amba Dongar complex, India. Mineralogical Magazine, 85, https://doi.org/10.1180/mgm.2021.50.

Yakovenchuk V.N., Ivanyuk G.Yu. and Pakhomovsky Ya.A. (1999) Minerals of the Khibiny Massif. Zemlya, Moscow [in Russian].

Yakovenchuk V.N., Ivanyuk G.Yu., Pakhomovsky Y.A. and Men'shikov Y.P. (2005) Khibiny (F. Wall, editor). Laplandia Minerals, Apatity, Russia, 467 p.

Yakovenchuk V.N., Nikolaev A.P., Selivanova E.A., Pakhomovsky Yф.A., Korchak J.A., Spiridonova D.V., Zalkind O.A. and Krivovichev S.V. (2009) Ivanyukite-Na-T, ivanyukite-Na-C, ivanyukite-K, and ivanyukite- $\mathrm{Cu}$ : New microporous titanosilicates from the Khibiny massif (Kola Peninsula, Russia) and crystal structure of ivanyukite-Na-T. American Mineralogist, 94, 1450-1458.

Zaitsev A.N., Spratt J., Shtukenberg A.G., Zolotarev A.A., Britvin S.N., Petrov S.V., Kuptsova A.V. and Antonov A.V. (2021) Oscillatory- and sector-zoned pyrochlore from carbonatites of the Kerimasi volcano, Gregory rift, Tanzania. Mineralogical Magazine, 85, https://doi.org/10.1180/mgm.2020.101.

Zubkova N.V., Pekov I.V., Chukanov N.V., Yapaskurt V.O., Turchkova A.G., Larikova T.S. and Pushcharovsky D.Yu. (2021) A highly hydrated variety of elpidite from the Khibiny alkaline complex, Kola Peninsula, Russia. Mineralogical Magazine, 85, https://doi.org/10.1180/mgm.2020.96. 